\title{
Organizational Training And Leadership Of Mosque Youth In Kerinjing Village
}

\author{
Mukhlis $^{{ }^{*}}$, Bernadette Robiani ${ }^{1}$, Taufiq $^{1}$, Suhel ${ }^{1}$, Nazeli Adnan ${ }^{1}$, Zulkarnain Ishak ${ }^{1}$, Sukanto ${ }^{1}$ And \\ Hamira $^{1}$ \\ ${ }^{1}$ Faculty of Economics, Universitas Sriwijaya, South Sumatra, Indonesia \\ * Correspondence author: mukhlis6473@gmail.com
}

Article Info: Received: 07 June 2021; Accepted: 03 November 2021; Published: 08 November 2021

\begin{abstract}
The current phenomenon of understanding of organization and leadership in mosque youth organizations is still relatively lacking and doesn't really understand how to manage an organization effectively and efficiently so that organizational goals haven't been achieved optimally. This dedication aims to provide motivation to the management of youth mosques in Kerinjing Village to be more optimal and effective in organizational management. The dedication was carried out by means of lectures, training, and simulations to the mosque youth administrators in Kerinjing Village. The material provided is in the form of materials related to issues of leadership, conflict management, organizational management, and trial techniques. Through this dedication activity, it is hoped that it can provide skills for the administrators of youth mosques in Kerinjing village in managing organizations, forming management structures, and generating leadership talents. The expected output from this dedication activity is in the form of a final report and an article in a dedication journal. The results of this dedication are also expected to be the basis for the government in making policies and programs related to youth issues in rural areas.
\end{abstract}

Keywords: leadership, conflict management, organizational management, mosque youth

How to Cite:

Mukhlis, Robiani, B., Taufiq, Suhel, Adnan, N., Ishak, Z., Sukanto, \& Hamira (2021). Organizational training and leadership of mosque youth in Kerinjing village. Sricommerce: Journal of Sriwijaya Community Services, 2(2): 139-146. DOI: https://doi.org/10.29259/jscs.v2i2.66

\section{INTRODUCTION}

Youth organizations are often used as a forum to do negative things that can upset the community, for example, there are fights between the community and youth organizations that take casualties, as well as fights between youth organizations one with another organization (Sudarsono, 2004). It is as if the youth organization is used as a place to show off their strength. Some people think that youth organizations are a place for brutal groups of people who create community unrest and destroy the younger generation (Widiatmaka et. al., 2016). Therefore, it is necessary to instill religious values in youth organizations. The inculcation of religious values in adolescents can be carried out in an organization carried out by youths who preach in mosques, which is an organization commonly known as the Masjid Youth (Siswanto, 2010). A mosque is an Islamic community development institution founded on the basis of taqwa and functions to sanctify the Islamic community that is fostered in it (Ayub, 2005).

The current phenomenon is a lack of understanding of organization and leadership in mosque youth organizations and not really understanding how to manage an organization effectively and 
efficiently so that the goals of the organization have not been maximally achieved. Therefore, through this training activity, it can provide information, knowledge and education on how to manage an organization, so that the mosque youth organization can run according to its predetermined goals (Majid \& Andaiyani, 2011).

To increase understanding and knowledge of organizational management in the mosque youth organization in Kerinjing Village, Tanjung Raja Selatan District, efforts can be made with basic leadership training. Through this training, it can motivate and provide knowledge for the management of mosque youth organizations in managing their organizations effectively and efficiently. Through basic leadership training, it is hoped that youth and adolescents will be aware of their position in society so that they can avoid unproductive activities such as consumption of illegal drugs, violence, and juvenile delinquency. In addition, all youth are expected to remain enthusiastic and maintain solidarity in supporting the activities and development programs of Kerinjing village. Through this training, leaders who are intelligent intellectually and spiritually can also emerge (Yusnaini et.al. 2021).

\section{LITERATURE STUDY}

\subsection{Organizational Theory}

Organization is a form of association of two or more people who interact and work together based on work relations and division of labor and activities arranged hierarchically in a structure to achieve a series of goals. Organizations are basically used as a place or a place for people to gather, work together rationally and systematically, planned, guided and controlled in utilizing resources, infrastructure, data, etc. which are used efficiently and effectively to achieve goals. Organization (Yuliana, 2012).

According to Hasibuan (2013), an organization is a formal, structured and coordinated union system of groups of people who work together to achieve certain goals. According to Siagian (2008), an organization is any form of partnership between two or more people who work together and are formally bound in order to achieve a goal that has been determined in a bond where one/ several people are called superiors and one/ a group of people who are called subordinates (Soediro et.al., 2021).

According to Gitosudarmo and Sudita (2010), an organization is a system consisting of a pattern of collaborative activities carried out regularly and repeatedly by a group of people to achieve a goal. According to Robbins and Judge (2007), an organization is a social unit consisting of two or more people, consciously coordinated, and functioning on a relatively continuous basis to achieve one or a series of goals.

An organization consists of 3 main elements namely people, goals and structure. So that the main functions of the organization are: a) as a forum for people to work together to achieve one goal; b) as a forum for people to shape organizational behavior and culture; and c) as a vehicle for achieving goals that are difficult to achieve alone. People in the organization eventually form a structure that supports the achievement of goals. The things that become variables in classical organizational theory, the importance of the role of managers, utilization and appointment of workers, responsibility for employee welfare and a conducive climate (Hamidi et.al., 2020). As for some of the originators of the classical theory, among others, namely:

1. Robert Owen. Emphasizes the role of human resources as the key to company success. The assumptions are motivated by inadequate working conditions and conditions, where the previous working conditions and the life of workers at that time were very bad.

2. Charles Babbage. Do the division of labor, so that each worker can be educated in a special skill. Each worker is only required to have specific responsibilities in accordance with his / her specialty.

3. Frederick W. Taylor. It is the starting point for the application of scientific management as a result of research on time $\&$ motion studies. By emphasizing the time for completion of work can be correlated with the wages received. This method is called the differential wage system. 
4. Hennry L. Gantt. The idea is mutual cooperation between managers and employees, recognizing appropriate selection methods and a system of bonuses and instructions. Gantt rejects the differential wage system, because it has little impact on work motivation.

5. Frank B. Gilberth and Lillian M. Gilberth. Based on the idea of research results about the relationship of movement and fatigue at work. According to Frank, movement and fatigue are related. Every movement that is eliminated also creates fatigue. According to Lillian, in order to achieve effective movement can reduce fatigue.

6. Herrington Emerson. Diseases that plague management systems in industry are waste and inefficiency. Therefore, within the organization there are clear objectives, logical activities, adequate staff, work discipline, fair remuneration, reliable reports, sequence of instructions, standardization of activities, standard conditions, standard operations, standard instructions and incentive remuneration.

\subsection{Leadership Theory}

Basic leadership theory, namely: genetic theory, social theory, and ecological or synthesis theory. The genetic theory explains that a leader is not made but someone emerges as a leader because of his extraordinary talents. A person becomes a leader because he is destined to be a leader regardless of the situation (Siagian, 2008; Solikin, Fatchurahman, \& Supardi, 2017; Yuliana et.al., 2020).

Social theory explains that leaders must be prepared and formed, not born and allowed to develop by themselves. To become a leader, everyone can do it through preparation, education and intentional training. Whereas ecological theory is a combination of both genetic theory and social theory, which explains that a person will be successful as a leader, if from birth he has had leadership talents, and these talents were developed through experiences and educational efforts, as well as with its environmental or ecological demands (Yudiaatmaja, 2013).

Leadership is a management function to influence, direct, motivate and supervise others in order to carry out planned tasks so as to achieve organizational goals and objectives. The leadership ability or leadership of a manager will greatly affect organizational performance, especially in terms of achieving organizational goals (Manullang, 2009).

Leadership according to Gareth Jones and Jennifer George (2003) is a process where an individual has an influence on others and inspires, encourages, motivates and directs their activities to help achieve group or organizational goals. According to Stephen P. Robbins (2003), leadership is the ability to influence a group towards achieving goals. Meanwhile, the definition of leadership according to Richard L. Daft (2003) is the ability to influence people who lead to the achievement of goals. From these definitions, it is very clear that leadership is a management function that is closely related to the achievement of organizational goals.

\section{MATERIALS AND METHODS}

The implementation of this community dedication activity was carried out between July December 2020 in Kerinjing Village, Tanjung Raja Selatan District, Ogan Ilir Regency, South Sumatra Province. Activities carried out in the form of training, lectures and discussions, with the management of the mosque youth organization include identifying problems and planning the development of the mosque youth organization going forward. The target in carrying out community dedication activities is in the form of socialization and training on organizational management and leadership for the Mosque Youth Association so that it is useful for administrators in running the organization effectively and efficiently. The participants were 30 people consisting of youth mosque administrators in Kerinjing Village, Tanjung Raja Selatan District, Ogan llir Regency. 


\section{RESULTS}

Table 1. Age Distribution of Training Participants

\begin{tabular}{ccc}
\hline Group & Frequency & Percent \\
\hline$<20$ years & 14 & 46,67 \\
$21-25$ years & 6 & 20,00 \\
$26-30$ years & 7 & 23,33 \\
$>30$ years & 3 & 10,00 \\
\hline
\end{tabular}

Sumber: Primary Data, 2020

The implementation of this community dedication activity was attended by 30 participants with an average age of 20 years, the participants were teenagers and mosque managers in Kerinjing Village. The participants of this dedication are in accordance with the expected target audience. There are several basic reasons that make organization important. First, the organization as a tool to achieve goals, because the organization performs an important function, namely by overcoming limitations as individuals, the organization allows us to achieve goals that are more difficult or impossible to achieve alone. Second, organization as a tool for preserving knowledge. We get the importance of organizations in preserving knowledge from organizations such as schools, universities, museums, study groups, student organizations, and others that strive to continue to preserve knowledge. Third, the organizational structure is a network of relationships in which work is divided into units and departments. This division of work assists in bringing specialization in various activities to concern. Fourth, the organizational structure helps to place the right people on the right jobs which can be done by selecting people for various departments according to their qualifications, skills and experience. It helps in correctly defining the job explaining the roles of each person.
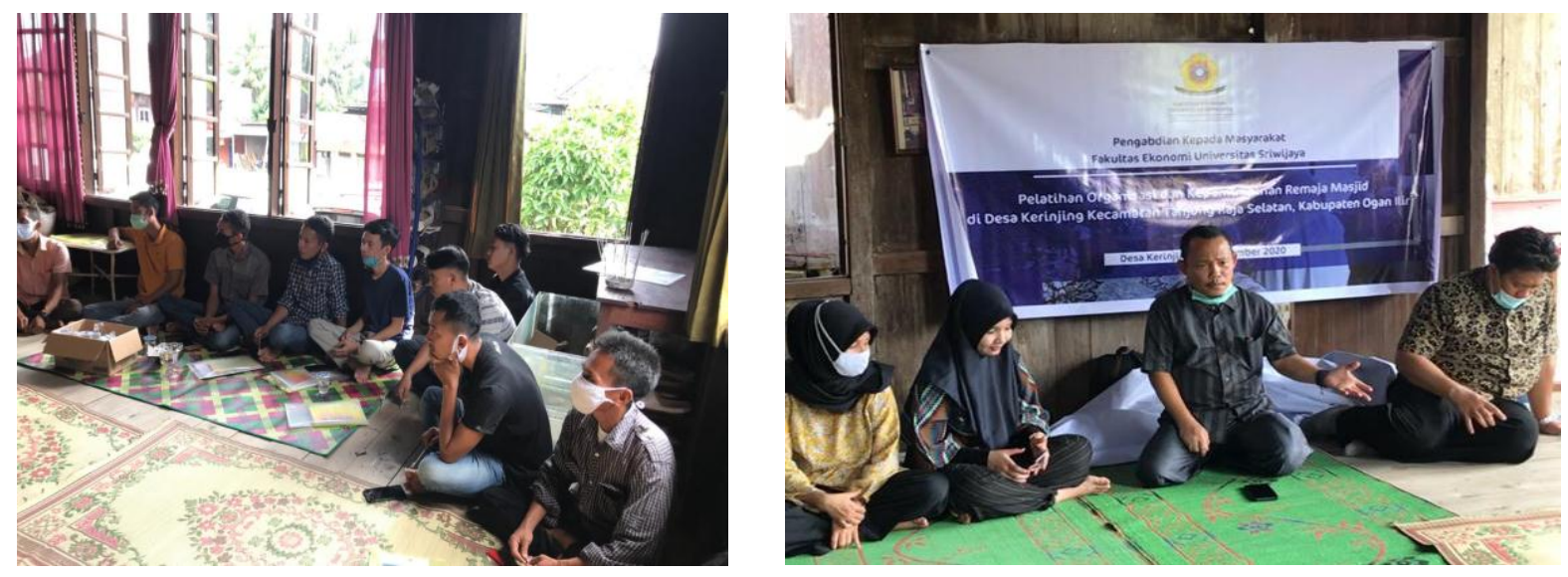

Figure 1. Presentation of Organizational Training and Leadership

Running an organization is not as easy as imagined, because the organization consists of many different people even though they have the same goal, but within the organization, of course there will be conflicts or organizational problems. This problem sometimes even arises in an organization that is already established and has experience. There is no coordination between members of the organization which often causes misunderstandings, which of course can lead to chaos in the implementation of a program. This chaos can occur when the people in charge do not know the limits of their duties. This will cause an imbalance in the implementation of work tasks because when there are members working on tasks, others experience job vacancies. This is certainly undesirable to happen in an organization, even by established ones. There is a process for solving problems in the organization, making decisions, strengthening team cohesiveness and getting appropriate and wise solutions: 
(1) Problem Definition: Identifying problems through problem formulation and asking questions. The key in defining a problem is asking the right questions to find the root of the problem. The framework that is often used is to use 5W1H (What, Who, When, Where, Which trends, and How big).

(2) Brainstorming: During the brainstorming process, assumptions are eliminated and the problem is further investigated. With the support of data, facts, and information that were previously unknown, it is getting closer to the root of the problem

(3) Selection: Decisions are taken together to determine the right and appropriate solution

(4) Development: When the teams in the organization find solutions and alternatives to a problem, the team will explore the pros and cons of each option and analyze the impact and other potential problems that may arise

(5) Action Planning The: Development and creation of an action plan ensures that the solutions obtained are executed and monitored in relation to problems that arise.

The emergence of conflict in an organization is not always negative. Conflict can be used as an excuse to make changes in the organization. This change can occur when managers conduct an evaluation of the differences in views between elements of the organization. This evaluation can lead to various conclusions and find new ways to solve problems that arise as a result of the conflict. Finding new ways to improve decision making. If existing conflicts can be developed into this, the emergence of conflicts can have a positive impact on the organization.

Leadership is understood in two senses, namely as the power to move people and influence people. Leadership is just a tool, means or process to persuade people to be willing to do something voluntarily/ joyfully. There are various factors that can move people because of threats, rewards, authority and persuasion. Leadership is the process of directing and influencing activities related to work for group members. This definition contains three important implications, namely: (1) leadership involves other people, both subordinates and followers, (2) leadership involves distributing power between leaders and group members equally, because group members are not powerless, (3) the ability to uses different forms of power to influence the behavior of his followers in various ways.
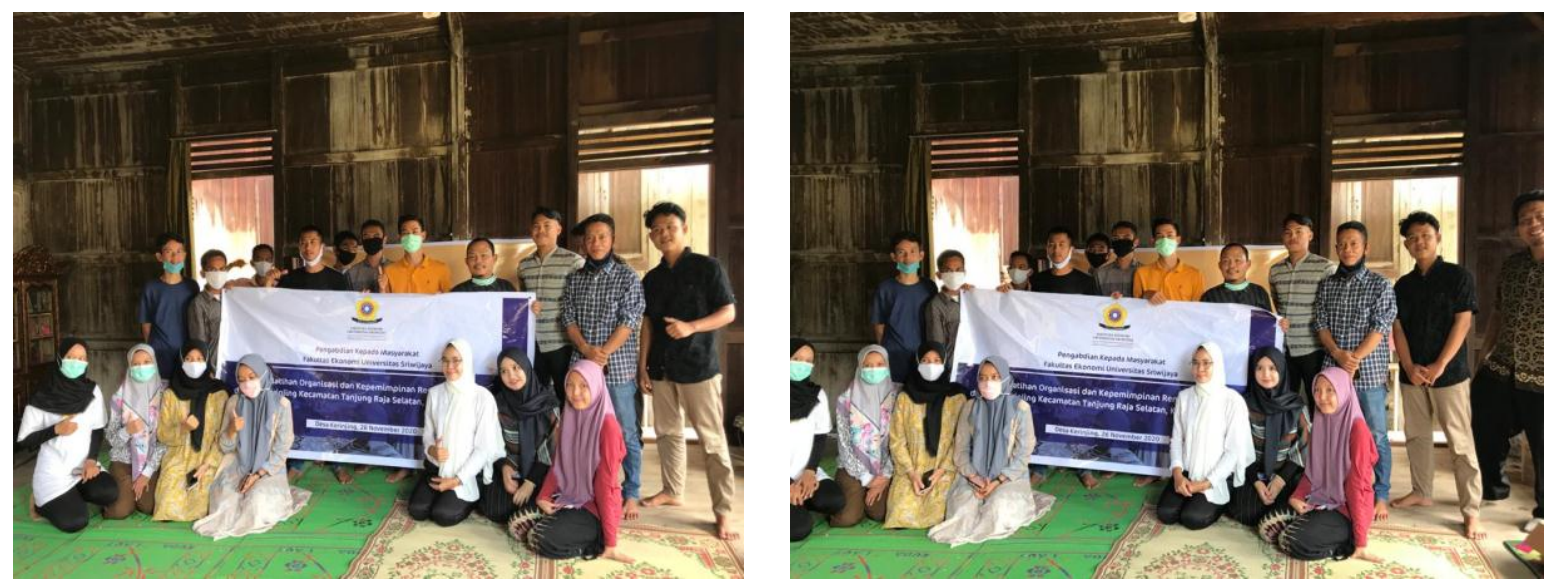

Figure 2. Participants of Organizational Training and Leadership

A leader is an optimist, a person who can see a better future. Not everyone can think like this. Especially if the current conditions are very bad. The ability to change the situation for the better is determined from the mindset, what can be done for a better future (Ambarita, 2013). To be a good leader, there are several things that must also be considered:

1) A leader is someone who knows himself well. A good leader is one who knows himself well too. That is, he knows his strengths and weaknesses. She understands how to use her strengths, but also understands what to do to correct her weaknesses.

2) A leader is a person of integrity. A good leader is a person who has integrity. That is, he is a 
person his team members can trust and rely on. With this integrity, team members can freely communicate with him. They will not hesitate to tell him about all the problems at hand. They believe that their leader will help them find a solution.

3) A leader is a person who respects others. Leaders are people who are considered better than other team members. Even so, a good leader is one who appreciates everyone, especially his team members. It has been said that a good leader is someone who knows himself. By knowing himself, he will realize that he has advantages and disadvantages. So, he will also realize that all members of his team also have their own strengths and weaknesses. A good leader is someone who is able to take advantage of the strengths of his team members, to complement the shortcomings of other team members. That way, the team's performance will always be maintained.

4) A leader is someone who can inspire. A good leader is someone who can inspire his team members. When there is a team member whose performance has decreased, then he must be able to make him show his good performance again. A good leader is a person who can make others a better person.

There are people who are born to be leaders. But there are also people who are produced to be leaders. This second type is a person who is tempered by circumstances, so that he can become a leader. It is unique and few people know that being a leader is not just being the smartest person in various fields in an organization. Leaders will get higher respect if they are able to regulate their emotional rhythm towards their subordinates, both in their work and personal life matters.

\section{CONCLUSIONS}

Through the implementation of community dedication activities regarding the organization and leadership training of mosque youths, the youth or youth of the mosque understand the organization, solving problems within the organization, and how to become leaders. The role of youth and youth plays a very important role for the future leadership. So, it is hoped that the role of the youth of the mosque can function as a mediator and facilitator of youth and youth activities.

\section{ACKNOWLEDGEMENT}

This activities was funded by Faculty of Economics, Universitas Sriwijaya. Thank you to the Faculty of Economics, Universitas Sriwijaya, lecturers, committees, students and villagers who have participated in the successful implementation of this activity, so that it can run well and provide benefits to the people of Kerinjing Village.

\section{REFERENCES}

Ambarita, B. (2013). Profesionalisme, Esensi Kepemimpinan, dan Manajemen Organisasi. Jurnal Generasi Kampus. 6(2), 1-16.

Ayub, M.E. (2005). Manajemen Masjid, Petunjuk Praktis Bagi Para Pengurus. Jakarta: Gema Insani. Damayanti, D. (2014). Panduan Implementasi Pendidikan Karakter di Sekolah. Yogyakarta: Araska.

Dewanta, P. \& Syaifullah, C. (2008). Rekontruksi Pemuda. Jakarta: Kementerian Pemuda dan Olahraga.

Fitri, A. Z. (2012). Pendidikan Karakter Berbasis Nilai dan Etika di Sekolah. Jogjakarta: Ar-Ruzz Media.

Gitosudarmo, I., \& Sudita, I. N. (2010). Perilaku Keorganisasian. Jogyakarta: BPFE.

Hamidi, I., Bashir, A., Atiyatna, D., Sukanto, S., \& Mukhlis, M. (2020). Pelatihan Manajemen

Koperasi Syariah di Desa Kerinjing, Kabupaten Ogan Ilir, Sumatera Selatan. Sricommerce:

Journal of Sriwijaya Community Services, 1(1), 9-16. doi:https://doi.org/10.29259/jscs.v1i1.5.

Hasibuan, M. (2013). Manajemen Sumber Daya Manusia. Jakarta: Bumi Aksara.

Kansil, C.S.T. (2017). Pancasila dan Undang-Undang Dasar 1945. Jakarta: PT. Pradya Paramita.

Khoir, S.R. (2017). Permasalahan Pemuda, Permasalahan Masa Depan. Website:

https://www.kompasiana.com/khoirsr/59f3d8c5ff240526aa0eaa04/permas alahan- 
pemuda-permasalahan-masa-depan.

Majid, A., \& Andaiyani, D. (2011). Pendidikan Karakter Perspektif Islam. Bandung: PT. Remaja Rosdakarya.

Manullang. (2009). Dasar-Dasar Manajemen. Yogyakarta: Gadjah Mada University Press.

Peraturan Menteri Sosial 77 HUK 2010 Tentang Pedoman Dasar Karang Taruna 2010.

Rafsanjani, H. (2017). Kepemimpinan Spiritual. Jurnal Masharif al-Syariah: Jurnal Ekonomi dan Perbankan Syariah, 2(1), 1-17.

Robbins, S.P. dan Judge. (2007). Perilaku Organisasi. Jakarta: Salemba Empat.

Samani, M., \& Hariyanto. (2003). Konsep dan Model Pendidikan Karakter. Bandung: PT. Remaja Rosdakarya.

Siagian, S.P. (2008). Manajemen Sumber Daya Manusia. Jakarta: Binapura Aksara.

Siswanto. (2010). Panduan Praktis Organisasi Remaja Masjid, Jakarta: Pustaka Al-Kautsar.

Soediro, A., Kusumawardani, M., Farhan, M., Adhitama, F., Yusrianti, H., Bashir, A., \& Hamidi, I. (2021). Literasi Ekonomi Islam menuju Pusat Industri Halal Dunia. Sricommerce: Journal of Sriwijaya Community Services, 2(1), 39-46. doi:https://doi.org/10.29259/jscs.v2i1.34.

Solikin, Fatchurahman, \& Supardi. (2017). Pemimpin yang Melayani dalam Membangun Bangsa yang Mandiri. Anterior Jurnal. 16(2), 90-103.

Sudarsono. (2004). Kenakalan Remaja, Jakarta: Rineka Cipta.

Sulityowati, E. (2012). Implementasi Kurikulum Pendidikan Karakter. Yogyakarta: PT Citra Aji Pratama.

Undang-Undang Republik Indonesia Nomor 40 Tahun 2009 tentang Kepemudaan (Lembaran Negara Republik Indonesia Nomor 148 Tahun 2009, Tambahan Lembaran Negara Republik Indonesia Nomor 5067).

Widiatmaka, P., Pramusinto, A., \& Kodiran, K. (2016). Peran Organisasi Kepemudaan Dalam Membangun Karakter Pemuda Dan Implikasinya Terhadap Ketahanan Pribadi Pemuda (Studi Pada Pimpinan Cabang Gerakan Pemuda Ansor di Kabupaten Sukoharjo Provinsi Jawa Tengah). Jurnal Ketahanan Nasional, 22(2), 180-198

Yudiaatmaja, F. (2013). Kepemimpinan: Konsep, Teori, dan Karakternya. Media Komunikasi FPIPS. 12(2), 29-38.

Yuliana, R. (2012). Peran Komunikasi dalam Organisasi. Jurnal STIE Semarang. 4(3), 52-58.

Yuliana, S., Rostartina, E., Teguh, M., Saleh, M., \& Apriani, D. (2020). Pengelolaan Dana ZISWaf Masjid Pintar di Desa Kota Daro II, Kecamatan Rantau Panjang, Kabupaten Ogan Ilir. Sricommerce: Journal of Sriwijaya Community Services, 1(1), 25-32. doi:https://doi.org/10.29259/jscs.v1i1.7.

Yusnaini, Y., Burhanudin, B., \& Khamisah, N. (2021). Training on the Preparation of Simple Financial Statements for Mosque /Mushollah and Youth Organizations of Mosque in the Kerinjing Village. Sricommerce: Journal of Sriwijaya Community Services, 2(1), 77-84. doi:https://doi.org/10.29259/jscs.v2i1.35. 
